\title{
'n Nuwe-Testamentiese perspektief op die kind
}

\author{
$A G$ van Aarde \\ Universiteit van Pretoria
}

\begin{abstract}
A New Testament perspective on children

A summary of the position of the child in the ancient times and, more specifically, biblical times is first given. After this attemion is focussed upon covenantai theology pertaining to the Reformation, and the position of the child in terms of it. Then follows an exposition of the Sitz im Leben of the so-called Kinderevangelium in Mark 10:13-16 and other corresponding passages. Lastly, suggestions are made concerning the way in which the child should be given an acceptable position in the church.
\end{abstract}

\section{INLEIDING}

Vir die doeleindes van hierdie studie gaan ons van die aanname uit dat die kerk 'n verbondsgemeenskap is, dat die plaaslike gemeente as die normale verskyningsvorm van die kerk op ' $n$ aangewese plek ' $n$ versameling van huishoudings is en dat ' $n$ kind sy/haar plek in die kerk as lid van 'n familie het. Wat die kind verder betref, meen ons dat hy/sy * steeds 'n randpersoon in die kerk is en dat hierdie verskynsel vanuit 'n Nuwe-Testamentiese perspektief nie die evangelie van Jesus Christus tot eer strek nie.

In die Nederduitsch Hervormde Kerk word die kind skaars raakgesien en gehoor. Waar dit wel gebeur, is dit gewoonlik by geleentheid van doop en kategetiese onderrig. Sal ons erken dat die belangrikste funksie van die kind in die Nederduitsch Hervormde Kerk hoofsaaklik dogmaties van aard is, en wel om as bevestiging van die teologiese konsep van die kinderdoop te dien? Die kinderdoop weer

\footnotetext{
* Referaat gelewer by die Predikantevergadering van die Nederduitsch Hervormde Kerk op 10 Sepiember 1991.

** Die manlike vorm word in hierdie studie voortaan in verwysing na die kind gebruik.
} 
vorm die teologiese vooronderstelling van die verbondsgedagte en die oortuiging dat die kerk volkskerk is. Maar die kind is tog op sigself nie 'n 'leerstuk' nie!

Vir die reformatoriese kerk is die plek van die gedoopte kind in die kerk om op pad te wees tussen sakramente - op pad tussen doop en Nagmaal. Hy is 'n 'gedoopte lidmaat' maar nog nie 'n 'belydende lidmaat' nie. Hy het klaarblyklik nie 'n ander rol te speel nie as om objek van kategetiese onderrig te wees sodat hy sy doop, maar veral die belydenis van sy geloof, sal verstaan. Eers dan kan hy in die openbaar sy plek as gedoopte èn belydende lidmaat inneem en objek van dissipline wees omdat hy nou die betekenis van sy doop ken en die onderskeiding tussen om gelowig en ongelowig te wees. Hy kan ook nou die geestelike voedsel by die Nagmaal ontvang want hy kan nou die ware betekenis daarvan ondersoek en die regte en verkeerde gebruik daarvan onderskei.

Omdat dissipline vir die reformatoriese kerk belangrik is, bied die Nagmaalsviering 'n goeie geleentheid om dit uit te oefen. Ten spyte van die oortuiging dat die kerk 'n corpus permixtum is, word dit in die reformatoriese kerk nodig geag om ter wille van die beskerming van die 'heiligheid' van die sakrament, die 'ongelowige' van die 'gelowige' by geleentheid van die Nagmaalsviering te probeer onderskei. In die Nagmaalsformulier (kyk ook Die Heidelbergse Kategismus, Sondagsafdeling 30, Vraag en antwoord 81 en 82) word die uitnodiging om Nagmaal te vier juis op die aspek van die 'selfondersoek' na aanleiding van 1 Korintiërs 11:28 gebaseer. Die selfondersoek word dan met die 'kognitiewe' in verband gebring. Juridies gesien bring kennis verantwoordelikheid mee en ontneem alle verontskuldiging. Dit is dan juis op grond van die lidmaat se voltooiing van sy kategetiese onderrig en aflegging van sy openbare belydenis, dat hy hom aan die kerklike dissipline kan onderwerp. Ook die jong lidmaat, net soos die ander lidmate, kan homself nou nie meer op grond van onkunde verontskuldig nie.

Kennis en geloof gaan dus vir die reformatoriese kerk hand aan hand (kyk ook o a Die Heidelbergse Kategismus, Sondagsafdeling 7, Vraag en antwoord 21). Dit is waarom dit belangrik is dat die gedoopte kind kategetiese onderrig moet ontvang. Eers na afloop van sy kategetiese onderrig en 'bevestiging van die geloof' by geleentheid van die 'openbare belydenis van die geloof' weet die kind wat sy doop beteken en dat sy doop hom van die ongelowige onderskei. Dit is eintlik ironies dat hiermee geïmpliseer v/ord dat, toe die gemeente voorheen as 'n versameling van huishoudings telkens sy geloof tydens eredienste bely het, die kind eintlik nog nie saam bely het nie omdat hy nog nie werklik geweet het waarop die geloof neerkom nie. Die ironie strek nog verder as in ag geneem het dat die kind in die Nuwe Testament juis as voorbeeld gebruik word om te verduidelik hoe iemand is wat glo. 
Dit wil voorkom asof dit 'n geregverdigde gevolgtrekking is dat die kind vir die kerk miskien net 'n middel tot 'n doel is. Enersyds is kindwees diensbaar gemaak in die debat wat reeds baie lank terug in die teologiegeskiedenis begin het, te wete die vraag na die verhouding tussen geloof en kennis. Andersyds, wat die Nederduitsch Hervormde Kerk betref, hoewel die wortels daarvan in die beginjare van die reformasie lê, bestaan die plek van die die kind daarin om uitórukking te gee aan die struktuur van die kerk as volkskerk. Ons bou ons kerklike struktuur en ons wyse van kerklike dissipline dus in terme van 'n konstruksie waarin ons die kind 'n spesifieke rol laat speel. In 'n volkskerk behoort ons egter daarteen te waak dat die 'struktuur en die handhawing van die dissipline belangriker as die Christologiese sentrum van die kerk word' (Pont 1987:43). Selfkritiek kan derhalwe heilsaam wees. Sonder om die geloofwaardigheid van die konsepte verbond', 'kinderdoop' en 'volkskerk' enigsins in gedrang te bring, lyk dit tog dat dit om verskeie redes belangrik geword het om die plek van die verbondskind in die kerk vanuit die perspektief van die Nuwe Testament te herwaardeer. Net soos die Nederduitsch Hervormde Kerk die plek van die vrou in die kerk as 'n volwaardige lidmaat herontdek het, word hy geroep om dieselfde met die kind te doen.

Victor Hugo het daarop geroem dat Columbus Amerika en dat hy die kind ontdek het. Maar die teoloog, Emil Brunner, het Jesus die 'ontdekker van die kind' genoem. Tien jaar gelede, in 1981, het Frank Jehle na afloop van die jaar van die kind', in 1979, 'n boek geskryf met die titel Augen für das Unsichtbare en daarin praat hy van die 'herontdekking van die kind'. So ook het daar in daardie tyd onder die stroom van literatuur die werke van onder andere Weber (Jesus und die Kinder), Rabe (Die Entdeckung der Kindheit) en Brechtken (Die Wiederentdeckung des Kindes) in 1980 verskyn (s v 'Kind' in Theologische Realenzyklopädie 1989:156-176). Ons bevind ons tans in die negentigerjare van die twintigste eeu. 'Nuwe wêrelde' word herontdek, maar die kerk het nog nie die kind herontdek nie. Hierdie studie wil bloot die punt van 'n ysberg uitwys. Vanuit 'n Nuwe-Testamentiese perspektief wil ons die saak beredeneer dat die kind nie meer 'n randpersoon in die verbonósgemeenskap behoort te wees nie. Die rol van die kind behoort méér te wees as dié van om slegs objek te wees van kategetiese onderrig en as bevestiging van grootmense se 'teologiese' idees en dispute - hoe belangrik ook al.

Eers bied ons 'n baie kort oorsig van die plek van die kind in die antieke tyd en in die besonder die Bybelse tyd. Vervolgens gee ons aandag aan die reformatoriese verbondsteologie en die plek van die kind in terme daarvan. Daarna bied ons 'n uitleg van die Sitz im Leben van die die sogenoemde Kinderevangelium in Markus 10:13-16 en in ander verwante tekste. En ten slotte suggereer ons voorstelle oor hoe 
daar vandag aan die kind as 'n volwaardige lidmaat 'n aanvaarbare plek in die kerk gegee kan word.

\section{DIE KIND IN DIE ANITEKE TYD}

Om 'volkskerk' te wees is om nie die wêreld te wil vermy nie, maar om kerstenend sin aan die wêreldse bestaan te gee. In die tweede/derde eeu $\mathrm{n} C$ het die anonieme skrywer van die bekende brief aan Diognetus gesê dat 'n Christen, ten spyte van sy eie onderskeidende karakter, inderdaad soos enige ander mens in die samelewing

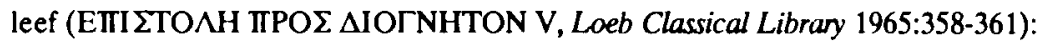

Want Christene verskil nie van die res van die mense wat betref hulle land, taal, of gewoontes nie. Hulle bewoon nêrens hulle eie stede nie, ook gebruik hulle nie een of ander eienaardige taal nie, ook beoefen hulle nie 'n seldsame lewenswyse nie...Maar terwyl hulle Griekse en nie-Griekse stede bewoon, soos dit vir elkeen bepaal word, en terwyl hulle die plaaslike gebruike volg wat sowel kleredrag as voedsel en die res van hulle lewe betref, vertoon hulle die wonderlike en paradoksale kenmerk van hulle eie burgerskap. Hulle bewoon hulle huise in hulle eie vaderland, maar is soos bywoners...Hulle trou soos almal, hulle bring kinders voort, maar hulle gooi nie hulle kinders weg nie ( $\dot{\alpha} \lambda \lambda^{\prime}$ ou

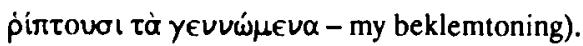

Die Griekse woord pirtw wat hierbo met 'weggooi' vertaal is, word op heelwat plekke gebruik om te verwys na die ostraserende handeling om iemand 'uit die huis of uit die land te sit' (kyk Liddel \& Scott 1961:1572). Dit is besonderlik op hierdie punt dat die onderhawige studie bloot die punt van 'n ysberg met betrekking tot die uitskuif van die kind tot die sosio-religieuse posisie van 'n randpersoon - 'n outcast, 'n non-account - in die Bybelse en klassieke tyd aanraak.

Bogenoemde opmerking in die Diognetus-brief is een van die mees eksplisiete verwysings na die wydverspreide Hans-und-Gretel-verskynsel dat kinders uit huise verstoot is vanweë ondere andere 'n primitiewe wyse van bevolkingsgroeikontrole en oorlewingsmotiewe (kyk Boswell 1984:10-33). Heelwat verwysings hierna word in die geskrifte aangetref van onder andere Lactantius (Institutiones Divinae 5.9), Justinus die Martelaar ( 1 Apol 27), Klemens van Aleksandrië (Paedagogus 3.3), Seneca (Controversiae 10.4.16) en Tertullianus (Ad Nationes 1.3.16). Dit is veral die

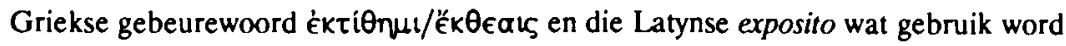
om na hierdie ostraserende handeling te verwys wat baie ooreenstemming toon met Middeleeuse gebruike toe kinders met kerklike goedkeuring en regulering aan kloosters 'geskenk' is (Deroux 1927), terwyl voorgegee is dat dit 'n godsdienstige 'offerhandeling' was. 
Soos die woorde 'warm' en 'koud' semanties nie los van mekaar gebruik word nie - die een vind sy betekenis in terme van die ander - vind die Griekse woord ék-

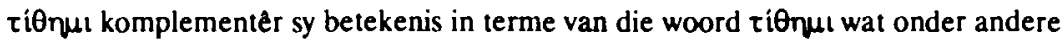
op 'n daad van 'verkiesing' kan dui (vgl Louw \& Nida 1988:483). 'Verkiesing' hoef nie altyd 'seleksie' te impliseer nie, maar ook die 'aanvaarding' of selfs die 'aanwysing/benoeming tot die vervulling van 'n spesifieke rol'. In die Bybelse tyd het naamgewing aan kinders deur ouers soms ook verband gehou met die aanwysing en roeping om ' $n$ bepaalde rol te vervul of ' $n$ taak te verrig (vgl Patte 1987:23-28 to v Josef se benaming as 'seun van Dawid' in die Matteus-evangelie, asook die naamgewing aan 'Jesus' as 'God-by-ons'). Dit is in hierdie verband belangrik om daarop te let dat die gebruik van 'n ouer om sy kind te seën en die hande op te lê (vgl die ana-

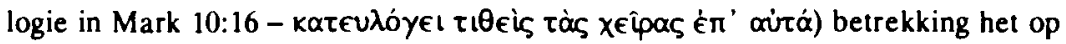
die handeling van 'aanvaarding in die huis' teenoor die 'uitsit uit die huis'. Om die kind te seën is om hulp en versorging te beloof. (Horst 1961:1650 verwys in hierdie verband na Rut 4:13-16.) Vanweë die verbondsverhouding tussen 'n kind en sy vader, is een van die belangrikste eerbetonings wat ' $n$ kind sy vader kan bewys, om op 'n resiproke wyse sy vader te versorg wanneer hy bejaard is, en om hom uiteindelik te begrawe. Die Griekse woord tiفnul word ook hiervoor gebruik (kyk Hand 7:16),

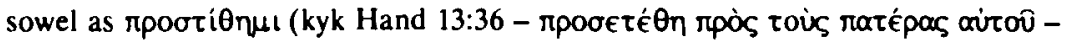
wat letterlik beteken 'om jou vader aan sy vaders toe te vertrou') (vgl Louw \& Nida 1988:531).

Dit is bekend dat oud-Israel in sy Umwelt meer 'n oog vir kinders as sy buurvolke gehad het. In Psalm 106:37 word Israel juis opgeroep om die heidense praktyk van kinderoffers te laat vaar (kyk veral die breedvoerige studie van Stager \& Wolff 1984 hieroor; vgl ook Thompson 1986:38-42). Dit beteken egter nie dat hierdie praktyk glad nie meer deur die Israeliete beoefen is nie. In Esegiël 16 word die verbondsluiting van God met sy volk vergelyk met die vind van 'n dogtertijie wat by geboorte weggegooi, maar deur God as ouer in terme van 'n verbondsooreenkoms versorg is. In die Stefanus-rede word Moses se 'uitsit uit die huis' (kyk Louw \& Nida 1988:728) in 'n doodsmandjie ook met die Griekse werkwoord ékri $\theta$ nut beskryf (Hand 7:21; vgl ook Eks 2:3 LXX).

Kinders is om verskillende redes 'uit die huis' gesit. Afgesien van 'n oorlewingsmotief of godsdienstige oorwegings, is kinders dikwels weggegooi' vanweë 'n ongewenste huwelik en swangerskap (Boswell 1984:19). Fisieke- en serebraal-gestremde kinders, blindes, diegene met slegs een oog of een arm, melaatses, stommes en dowes is dikwels op hierdie wyse geostraseer (Stockton 1983:90). Die Romeinse filosoof en staatsman, Seneca, tydgenoot van Jesus en bekend vir sy oproepe tot 
barmhartigheidsgesindheid (kyk Dibelius 1961:1694-1695), verwys na voorvalle in hierdie verband (kyk Boswell 1984:21 n 26; vgl ook Rawson 1986:170-200).

In die Ou Testament is die analogiese verwysing in Esegiël 16:3 na die weggooi van 'n kind juis as gevolg van 'n omgewenste gemengde huwelik. Noukeurige studies is reeds gedoen in verband met die verbod op gemengde huwelike tydens veral die regering van die laaste Judese konings (kyk o a Epstein 1942). Dit is die nawerking van hoofsaaklik Esra se na-eksiliese huwelikhervormingsmaatreëls (kyk o a Bossman 1979:32-38) wat ten tyde van die eerste-eeuse Farisese reinheidsmaatreëls daartoe gelei het dat egskeiding op grond van die wette van 'Moses' geregverdig is (kyk Mark 10:1-10 en par). Hierdie toedrag van sake het veral gelei tot die ostrasering van die 'onrein' vrou en haar oudste kind (vgl ook Bakon 1981:10-19; Meijer \& Meijer 1984:81-87; Goodnick 1988:170-178; asook Weaver 1986:145-169 m b t die periode van die Romeinse Ryk). Die egskeidingsdebat tussen Jesus en die Fariseërs oor die regverdigheid daarvan al dan nie (Mark 10:1-10) en sy medelyde met en aanraking (tydens 'n ete in die huis van 'n Fariseër) van die onrein vrou wat 'n 'sondares' genoem en uit die huis gesit is (Luk 11:36-50), moet waarskynlik teen hierdie agtergrond verstaan word. Dit is 'n verskynsel wat vandag steeds voorkom. In die Transvaler (1991-06-25, bl 7) lees ons die volgende berig oor jong vroue (wat waarskynlik volgens Westerse standaarde nog 'kinders' sal wees) wat 'uit die huis gesit is':

Sowat 15 jong Arabiese vroue het gister [24 Junie 1991] in Nasaret, Israel in 'n ongewone betoging beswaar gemak teen die doodmaak van vroue deur hulle manlike familielede omdat hulle die familie in die skande sou gesteek het. Dié vroue sê sowat 40 jong vroue word jaarliks vermoor nadat hulle buite-egtelik swanger geraak het, liefdesverhoudinge het wat nie goedgekeur word nie of met mans wil trou wat nie deur hul[le] familie as goed geag word nie.

Hierdie verworpelinge word gewoonlik aan allerlei sosiale ellendes uitgelewer. In die Nuwe-Testamentiese tyd was ander groepe randpersone, die hoi polloi (Horseley \& Hanson 1985:69) wat buite die kring van die normale familiale versorging probeer bestaan het, dikwels die uitgeworpe vrou en/of kind se enigste heenkome. In Matteus 4:23-25 en 15:29-32 word daar na hierdie mense as die Joodse skare (ol óx$\lambda \circ t)$ verwys. Hulle was die mense wat buite die kring van die normale versorgende huishouding bestaan het en wat maklik op pad sonder kos kon beswyk het. Onder hulle was daar fisieke- en serebraalgestremde mense (kyk Van Aarde 1991a, 1991b). Die Joodse historikus, Josefus, verwys op baie plekke na hierdie sosio-ekonomiese groep - die 'bandits' (kyk Horseley 1979:37-63) - wat volgens die Joodse reinheidsmaatreëls sosio-religieus verag is (kyk o a Neusner 1975:15-26), uit 'huise gesit is' en 
toegang tot die tempel en die sinagoges geweier is (vgl Elliott 1991a:100; Van Aarde 1991c). Saldarini (1988:44) verwys na hulle as die 'expendable class, about 5-10\%, for whom society had no place or need. They had been forced off the land because of population pressures or they did not fit into society. They tended to be landless and itinerant with no normal family life and a high death rate'.

Die Christelike apologeet, Lactantius (ca 250-325 n C) het daarop gewys dat kinders wat so weggegooi is, dikwels wilde diere of seksuele misbruik ten prooi geval het (Institutiones Divinae 5.9). Ook Justinus die Martelaar (ca 165 n C) het betoog dat Christene geleer moet word om nie hulle pasgebore kinders uit die huis te sit nie, want bykans al sulke kinders, dogters sowel as seuns, sal as prostitute misbruik word (1 Apol 27). Klemens van Aleksandrië (ca 160-215 n C) wys insgelyks op dieselfde ellende en meld ook dat mans later onbewustelik met hulle eie kinders as prostitute seksueel kan verkeer (Paedagogus 3.3). Tertullianus (ca 160-212 n C) maak beswaar teen die gebruik om kinders uit die huis te sit omdat die kinders seer sal kry. Hy gee wel toe dat dit nie gewoonlik die bedoeling van die ouers was om hulle kinders leed aan te doen nie, maar dat vreemdelinge op grond van medelyde die kinders sou aanneem en beter sou versorg as wat die ouers dit self vanweë beperkte middele sou kon doen (Ad Nationes 1.3.16).

Die 'swakkere geslag' funksioneer in die Bybel baiekeer as 'n geskikte metafoor om God se bemoeienis met die mens mee uit te druk (vgl o a Hos 11:3-4). In die antieke en klassieke tyd is randpersone soos vrouens en kinders daarom dikwels in die godsdiens as draers van goddelike boodskappe gesien (Wiedemann 1989:176208). Dit is nie net omdat randpersone onheilspellende figure is en daarom geskikte boodskappers van orakels is nie. En dit is ook nie net omdat klein kinders die waarheid meer onvervals vertel nie (Ps 8:3). Die krag en mag en redding van God word eenvoudig duideliker analogies uitgedruk in terme van die swakkeres in die samelewing. Eweneens word die lewegewende, versorgende, beskermende en dissiplinerende bemoeienis van God eg ervaar as dit in terme van die verbondsverhouding tussen ouers en kinders (maar ook dié tussen man en vrou in die huweliksverbintenis) gesien word. Jesus het volgens die Nuwe Testament juis sy volgelinge daarop gewys dat die koninkryk van God as 'n 'ruimtelike gebeurtenis', en die gelowige se plek daarin, treffend voorgestel kan word as ' $n$ huis van ' $n$ vader wat baie kamers het waarin die vader saam met sy afhanklikes woon (Joh 14:2, 18, 23). Jesus word hier voorgestel as 'n vader wat sy volgelinge nie soos weeskinders sonder versorging sal agterlaat nie.

Die kulturele rol van 'n vader teenoor sy kind in die Nuwe-Testamentiese tyd het nie wesenlik sedert dié in die Ou-Testamentiese tyd verander nie (vgl Neyrey [1991]). 'n Vader het sy kind die lewe gegee deur hom te verwek. Sy kind is daarom 
lewenslank aan hom eer verskuldig. Sy bestaan in die huis en in die land is in der waarheid daarvan afhanklik. Deur sy kind te aanvaar, sluit die vader 'n verbond met sy kind. Die vader as sterkere neem die inisiatief in hierdie bilaterale verhouding wat op absolute lojaliteit gebou is. Die vader wat die lewe geskenk het, se eer is daarvan afhanklik dat hy sy kind in die lewe sal hou deur hom te beskerm, te versorg en te akkommodeer. Die kind se verhouding met sy vader berus op absolute gehoorsaamheid aan die wil van sy vader. Wedersyds sal die kind daarom sy vader nie beskaam nie. Dit is inderdaad die geval van aartjie na sy vaartjie. Hy sal sy vader nie besteel nie, nie slaan nie, nie bespot nie en as hy oud geword het, hom beskerm, versorg en akkommodeer. Die laaste eer wat die kind sy vader sal betoon is om hom by sy afsterwe 'aan die voorvaders toe te vertrou'.

Die legkaart wat ons in die Nuwe Tetament met betrekking tot die kindskaptema aantref, word nou ietwat duideliker. Die Goddelike geboorte van Jesus, sy naamgewing en doop dui op sy roeping om bevryder te wees want dit sal sy versoeningstaak as God-by-ons wees om die 'sondes van die volk' weg te neem. As Seun van God het Hy sy dissipels geleer om as kinders van God hulle Vader in die hemel te eer, Hom gehoorsaam te wees, hulle dag se brood uit sy hand te ontvang en dat hulle hulle nie moet skaam om daarvoor sonder ophou te bid nie. God is vir die gelowige $A b b a$. Hy gee die lewe en nie die dood nie (vgl Matt 6:1-18; Luk 11:1-13). Net soos kinders sonder ' $n$ teenprestasie daarop kan vertrou dat waaragtige lewe vir hulle in die huishouding gegun sal word, is mense se geloof in God as Vader egter nie soos by die eerste-eeuse Jode op sigself afhanklik van die kennis van die Tora as teenprestasie nie. Die vertroue van 'n kind is om absoluul innig afhanklik van sy vader te wees. Heelwat vertellinge in die Nuwe Testament toon aan dat die bevryding vanuit die mag van die sonde met so 'n geloofshouding gepaard gaan. Dit is in hierdie opsig dat Jesus tereg die eer kry om die 'ontdekker van die kind' genoem te word. Dit was Jesus wat dié eienskappe van wat tipies kindwees is, as eksemplaries uitgewys het van wat dit is om gelowig te wees.

Dit is in hierdie opsig dat die kerk tot vandag toe nog nie werklik die kind ontdek het nie. Dit wat tipies kindwees is, bepaal nie die plek van die kind in die kerk nie. Dit wat grootmenswees is, bepaal die plek van die kind in die kerk. Sedert die Reformasie is die voorwaarde van die 'konfirmasie' van die kind as kind van God uitgebrei en is dit nie meer net die kennis van die Tora wat die kind se opname in die verbond sal bevestig nie, maar ook sy kennis van die Ons Vader-gebed en van die Kategismus (kyk ook die standpunt van Pel 1968:42-60). In die Rooms-Katolieke Kerk was die monastiese skoolonderrig daarop gerig om die kind vanaf die sakrament van die doop voor te berei sodat hy die handoplegging by geleentheid van die sakrament van die vormsel kan ontvang. Die vormsel verleen weer toelating tot die 
sakramentele gemeenskap van die heiliges by die Nagmaal. Hierteenoor sien die reformatoriese kerke die kategetiese onderrig as kennisoordrag sodat die kind sy doop sal begryp en by geleentheid van die openbare geloofsbelydenis dit bewustelik sal sê. Enkel en alleen op grond van veral die kerk se verstaan van die imperatief

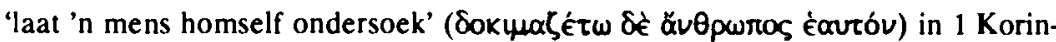
tiërs 11:28 word die doop van die kind nie gesien as sy volledige opname in die verbondsgemeenskap nie, maar word kennis by die geloofsvertroue vereis voordat die doop 'bevestig' kan word en die kind ten volle deel kan kry aan die gemeenskap van die heiliges deur die brood van die lewe by die Nagmaal as verbondsmaaltyd te ontvang.

In die tyd vo6r Jesus is die gebrek aan kennis nie net gesien as die uiterlike sigbare en kenbare onderskeidingsteken tussen die gelowige en ongelowige nie, maar ook as legitimering om mense bewustelik uit die verbondsgemeenskap uit te sluit. Die Fariseërs het na diesulkes verwys as die 'volk van die land' (am ha'arez). Dikwels is hulle maar dieselfde groep mense waarna ons vroeër verwys het as diegene wat 'uit die huis' en 'uit die land' gesit is.

In hierdie studie wil ons aantoon dat die sogenoemde Kinderevangelium, Markus 10:13-16, oftewel 'die sëen van kinders met handoplegging' wat Calvyn teenoor die Rooms-Katolieke vormsel asook die Lutherse Confirmation alleen met die doop van kinders verbind het, nie as die beginpunt van 'n proses (van kennisverkryging) gesien moet word nie en nie as legitimering van die proses van ekskommunikasie van andersdenkendes of andersoortiges nie, maar as aanduiding van die volwaardige plek van die kind in die kerk as verbondsgemeenskap. Nieteenstaande die feit dat ons die Nuwe-Testamentiese konteks van die Kinderevangelium nie soos die Reformatore interpreteer deur dit, teenoor die Wederdopers, in verband te bring met die kinderdoop as sodanig nie, kan Markus 10:13-16 en verwante tekste steeds as die locus classicus van die Nuwe-Testamentiese perspektief op die verbondskind gesien word.

\section{DIE KIND IN TERME VAN DIE VERBONDSTEOLOGIE}

Om vanuit die perspektief van die reformatoriese tradisie die kind in die lig van die verbond te sien, voer ons onwillekeurig terug na die reformatoriese doopformulier. Dit laat ons terugdink aan 10 Augustus 1523 toe Zwingli (1484-1531) in die Grozzmünsterkerk in Zürich vir die eerste keer die doop aan kinders bedien het aan die hand van die formulier wat hoofsaaklik deur Leo Jud opgestel is (Fugel 1989:377446; Storm 1985:402-411) Die teologie grondliggend aan hierdie formulier is hoofsaaklik bepaal deur Zwingli se refleksie op die aard van die burgerlike gemeenskap onder leiding van die owerheid vanuit 'n teokratiese perspektief (Fugel 1989:107- 
118, 263-275; Pont 1985:430-434; Van der Walt 1990:134-142). Hierdie teologie word die 'reformatoriese verbondsteologie' genoem. 'n Reformatoriese verbondsteologie in die volle sin van die woord is egter eers deur Zwingli se opvolger, te wete Bullinger (1504-1575), uitgewerk (Botha 1985:412-427). Hierdie teologie is veral gekenmerk deur sy bilaterale aard wat nie net God se inisiatief met betrekking tot die inlywing van die mens in die gemeenskap as verbondsgemeenskap beklemtoon nie, maar ook die verbondsverpligtinge van die mens (Smith 1985:387-401).

Die begrip verbondsgemeenskap' hoef nie bloot as 'n dogmatiese leerstuk hanteer te word wat in die lug hang of hoogstens in 'n belydenisskrif geformuleer is en slegs kognitief beheer of juridies aangewend word nie. Die verbondsteologie wat in die doopformulier uitgedruk word, kan ook gesien word as die produk van mense van vlees en bloed wat daarmee uitdrukking gegee het van hulle oortuigings rakende God se plek in die daaglikse lewe van die gemeenskap. Die aard van die gemeenskapslewe in die tyd v66r die Hervorming is nie meteen in alle opsigte wesenlik deur die ontluikende 'verbondsteologie' verander nie. Pont (1991) meen wel dat die kind v6or die Reformasie afgeskeep is en dat dit gesien kan word in die afwesigheid van kategismusse met die oog op die onderrig van kinders. Tog moet ons in die lig van ons vorige opmerkings daarop wys dat Tomas van Aquinas (Summa Theologiue 2a2ae.88.9, 2a2ae.189.5, 2a2ae.189.5.2; Quodlihetales 3.5.11.12, 4.12.23, 4.12.23.7) in besonderhede ingaan op die onderrig van kinders in die kloosters, op die kwessie dat kinders wat nog nie verstaan waarop dit neerkom nie, nie deur 'n eed lewenslank gebind kan word nie en op die vraag of sulke kinders buitendien enige plek in die kloosterlewe het. Dit wil egter voorkom of ons nie hier werklik 'n besorgdheid oor die kinders as sodanig aantref nie, maar dat die groot getalle kinders wat deur ouers aan die kerk geskenk is en in der waarheid eintlik op dié wyse uit die huis gesit is, die kerklike lewe ontwrig het (kyk Boswell 1984:29). Hierdie 'kinderoffers' is oblatio genoem en is alreeds in die eerste eeu $\mathrm{n} C$ deur Seneca (Controversiae 10.4.16) onderskei van expositum (kyk Boswell 1984:14 n 4).

Deurgaans in die Middele eue het die kerk kinders wat uit die huis gesit is, ontvang en onder andere as 'n soort 'kinderhuis' gefunksioneer. In 'n sekere sin het die kerk hierdeur die ostraserende praktyk gefasiliteer. Reeds in die Middeleeue het dit vir die kerk belangrik geword om die doop en die terugeis van expositi te reglementeer (kyk Boswell 1984:16). Sesde-eeuse kerklike formules is aan ons bekend wat selfs die verkoop van kinders gereël het. Veral binne die Benediktynse Orde vind ons dat oblatio goedgekeur is. Ouers is deur reglemente egter verbied om verder inspraak in die onderrig en opvoeding van hierdie kinders te hê. Die onderrig van hierdie kinders is ook onderskei van die normale onderrig wat aan kinders in die kloosters verleen is (kyk Boswell 1984:17). Aanvanklik is kinders van slegs aris- 
tokrate ontvang, maar later ook dié van ouers uit die boerestand. In die dertiende eeu het die pouslike Decretum Gratiani die praktyk van oblatio begin verbied en is daar gepoog om nie kinders onder die ouderdom van agtien jaar in die kloosters te ontvang nie (Boswell 1984:25).

Dit wil dus voorkom dat, hoewel die Rooms-Katolieke sakrament van die vormsel deur die Reformatore met die konfirmasiegedagte vervang is, kinders in werklikheid nog steeds dieselfde sosio-religieuse posisie as voorheen gehad het. Steeds was daar die neiging om kinders onder bepaalde omstandighede as ' $t$ ware te ekskommunikeer. En wat die kinders betref wat wel in die huis geakkommodeer is, is hulle steeds onder leiding van hulle ouers op dieselfde wyse as voorheen deur middel van die doopseremonie in die gemeenskap ingelyf. In hierdie gemeenskap - vóor of ná die Hervorming - is die kerk nie gesien as 'n selfstandige, eiesoortige liggaam in die gemeenskap nie (Pont 1985:431; Haas 1969:216-222). 'n Mens kan sê dat 'doopregistrasie' 'n soort 'geboorteregistrasie' was. Die eenheid tussen die burgerlike gemeenskap en die kerklike gemeenskap in die tydperk van Rooms-Katolieke beheersing wat sedert die Konstantynse periode bestaan het, het daartoe aanleiding gegee dat die samelewing as die corpus Christianum bekendgestaan het. Wat met betrekking tot die visie op die gemeenskap verander het as gevolg van die Zürichse hervorming, is dat Bullinger die term corpus respublica Christianum begin gebruik het (Pont 1985:433). Hiermee is wat die gemeenskap betref, die klem na die gemeenskap as verbondsgemeenskap verskuif. Steeds was daar net éen gesagsdraer in die gemeenskap en dit was die burgerlike owerheid. Die kerk, sy lewe, finansiering, orde en inrigting is bepaal deur maatreëls van die burgerlike owerheid (vgl Pont 1985:431; Baker 1980:xxiii). Die voorrang wat die Heilige Skrif op grond van die Hervorming gekry het, is dat die Ou Testament gesien is as die model waarvolgens die gemeenskap as verbondsgemeenskap bestaan het. Soos 'n koninklike figuur in die Ou Testament, moes die Christelike magistraat wat volgens die Bybel deur God aangestel is, oor die volk van God aan die hand van die Tien Gebooie regeer (Pont 1985:433-434). Sodoende het hy sorg gedra dat die volk as verbondsgemeenskap bewaar, die verbondsverpligtinge nagekom en daar in vroomheid gelewe word (kyk ook Pont 1986:30; Fugel 1989:315). Hierin was die magistraat deur die prediking van die verkondiger van die Woord begelei (Pont 1985:433).

Godsdienstige verdraagsaamheid het nog nie bestaan nie. Kerklike dissipline was op grond van die toedoen van onder andere Calvyn selfs uitgeoefen op mense wat in besit was van Rooms-Katolieke literatuur (s v 'Calvin', TRE 1981:573). Ook is die Anabaptiste sterk deur onder andere $\mathrm{Zwingli}$ en Bullinger bestry. Hierdie anti-anabaptistiese teologie van die Zürichse Hervorming het ook deurgewerk na die opstellers van die Heidelbergse Kategismus (1560), Ursinus en Olevianus. Wat 
in hierdie opsig opvallend is, is dat die Heidelbergse Kategismus in Sondagsafdeling 27, Vraag en Antwoord 74 die volgende woorde bevat: 'Daarom moet hulle (jong kinders) ook deur die doop as teken van die verbond in die Christelike kerk ingelyf word en van die kinders van die ongelowiges onderskei word'. Sosio-religieuse onverdraagsaamheid wat op spesifieke historiese omstandighede betrekking het, kan tussen die reëls van hierdie woorde gelees word.

Die prominente plek wat die kind in die Zürichse doopformulier sowel as in die Tweede Switserse Geloofsbelydenis en in die Heidelbergse Kategismus gekry het, moes dus nie soseer aan die invloed van die Hervorming toegeskryf word nie. Die feit dat die Reformasie geboorte gegee het aan 'n proses van die opstel van kategismusse met die oog op die onderrig van kinders en bulle openbare geloofsbelydenis (kyk Pont 1991), het nie te doen met 'n stryd wat die Reformatore met die RoomsKatolieke Kerk sou gehad het oor die plek as sodanig van die kind in die geloofsgemeenskap nie. Miskien is daar twee redes vir die prominensie van die kind in die reformatoriese doopformulier: Aan die een kant is die dopeling deur middel van sy inlywing in die corpus respublica Christianum onbetwisbaar onder kontrole geplaas sodat sy 'uitverkorenheid' deur ekskommunikasie beëindig kon word indien hy later as volwassene na aflegging van sy openbare geloofsbelydenis die verbond en dié se verpligtinge miskien sou verwerp deur onder andere te neig om terug te keer na die Rooms-Katolieke lewenswyse en teologiese opvattings; andersyds is die anabaptistiese opposisie simbolies teëgestaan met 'n beroep op die bewaring van die eenheid van die Ou en Nuwe Testament deurdat die verbond met Adam, Henog en veral met Abraham in kontinuum gesien is met God se handelinge in en deur Johannes die Doper, en veral Jesus Christus (vgl Botha 1985:416-417; Koch 1968:369-399).

Spore van godsdienstige verdraagsaamheid is wel vir die eerste keer in die opstel van die Augsburgse Geloofsbelydenis van 1555 aanduibaar (Pont 1985:434). Dit was egter veral die staatsteoretikus en vriend van die Protestante, Jean Bodin (1529-1596), wat daarteen geprotesteer het dat godsdienstige eenheid beskou word as die bestaansvoorwaarde van die Heilige Romeinse Ryk as staatsinstelling. Hy bepleit die onpartydige beoordeling van dispute van godsdienstige aard (kyk Kantenbach 1961:940). 'n Ontwikkeling in teologiese denke is daarmee op grond van sekularisering begin wat daartoe gelei het dat godsdiens nie meer gefunksioneer het as die basis van die staat nie, maar gesien is as 'n private aangeleentheid. Vandag word dit glad nie meer van die owerheid verwag om wetlik toe te sien dat verbondsverpligtinge nagekom word nie. 'Opvoeding en onderwys' word ook nie gesien as 'verbondsonderrig' nie. Die omstandighede waaronder die doopformulier ontstaan het en tot die besondere aksentuerings in die formulering daarvan aanleiding gegee het, het met ander woorde heeltemal verander. 
Bogenoemde inligting bring ons tot die besef dat ons nadenke vandag oor die plek van die kind in die kerk as verbondsgemeenskap nie net sonder meer vanuit die doopformulier afgelei kan word asof die sosio-religieuse omstandighede in die samelewing van destyds presies dieselfde is as vandag s'n nie. Wat is daar dan in die Zürichse doopformulier, sowel as in die Heidelbergse Kategismus, wat ons as vertrekpunt kan gebruik om op grond van ons Skriftuurlike nadenke oor die plek van die kind in die kerk as verbondsgemeenskap iets betekenisvol vandag te kan sê? Die saak wat miskien beklemtoning verdien, is die feit dat die verbondsteken aan die een kant gefunksioneer het as dié onderskeidingsteken tussen 'gelowiges' (hervorminggesindes) en 'ongelowiges' (Anabaptiste en Rooms-Katolieke) en aan die ander kant as teken dat die kind van gelowiges op geen wyse minder kind van God is as die ouers self nie.

Wanneer reformatoriese kerke vandag in Suid-Afrika steeds die verbondskarakter van die gemeenskap beklemtoon, is dit dus alleen 'n kerklike aangeleentheid. Die publieke ruimte wat die staat vir kind-gesinverhoudinge skep en bewaar, raak sake soos die onderwys. Vanweë 'n nuwe soort politieke en sosiale verdraagsaamheid sal hierdie owerheidsbetrokkenheid ook in 'n toekomstige Suid-Afrika verander sodat die situasie hier ook sal word soos in ander Westerse lande. Die kerklike gemeenskap staar daarom nuwe uitdagings in die gesig. Die verbondskarakter van die geloofsgemeenskap verskaf myns insiens steeds die verwysingsraamwerk waarbinne die evangeliese waardes wat die kerk koester, deur Christene in 'n nuwe SuidAfrikaanse situasie verwerklik kan word. Maar dit hoef nie te beteken dat ons die sestiende-eeuse polities-kerklike situasie in Europa teen ons beterwete moet laat probeer voortleef in Suid-Afrika nie. Die teokrasiegedagte soos dit destyds polities geïmplementeer is, kan eenvoudig nie net so vandag toegepas word nie. Die nastreef daarvan sal hoogstens 'n ideologie wees maar oor die algemeen gesien, sal dit nie grondvat nie. Laat ons wel die reformatoriese beginsel van Skriftuurlikheid handhaaf en opnuut kyk wat met die verbond in die Bybelse tyd bedoel kon wees. Sodoende kan ons aan die een kant getrou bly aan ons reformatoriese tradisie deur die kerk primêr as verbondgemeenskap, die doop as verbondsteken en die Nagmaal as verbondsmaaltyd te sien, en terselfdertyd die voorrang van die Bybel in ons teologiese nadenke in 'n nuwe situasie handhaaf.

Wat opvallend is, is die prominente plek wat Markus 10 in die Zürichse doopformulier (en Heidelbergse Kategismus) inneem (kyk ook Fugel 1989:434; Storm 1985:406, 410). Net voordat die doop aan die kind bedien is, het die leraar die volgende woorde uit die formulier gelees wat aan Markus 10 ontleen is: 
Die mense het kinderties na Jesus toe gebring dat Hy hulle moes aanraak. Sy dissipels het met die mense daaroor geraas. Maar toe Jesus dit sien, was Hy verontwaardig en het $\mathrm{Hy}$ vir hulle gesê: 'Laat die kindertjies na My toe kom en moet hulle nie verhinder nie, want die koninkryk van God is juis vir mense soos hulle. Dit verseker Ek julle: Wie die koninkryk van God nie soos 'n kindjie ontvang nie, sal daar nooit ingaan nie.' Hy het sy arms om die kindertjies gesit, hulle die hande opgelê en hulle geseën.

(Mark 10:13-16)

Hoe moet ons die betekenis van hierdie woorde vanuit 'n Bybelse perspektief op die verbond verstaan? Vanuit die situasie in die Nuwe Testament gaan ons vervolgens probeer om die plek van die kind in die ouergemeenskap ten tyde van Jesus se lewe op aarde te bepaal sodat die evangelie van Jesus Christus vandag lig vir ons kan werp op die situasie. Voordat ons die Sitz im Leben van Markus 10:13-16 bespreek, gaan ons eers kortliks en veralgemenend in op wat as 'n Nuwe-Testamentiese perspektief op die verbondskind bestempel kan word. Teoretiese en metodologiese sake wat ten grondslag van ons ondersoek lê, word sover as moontlik vermy.

\section{4. 'N NUWE-TESTAMENTIESE PERSPEKTIEF OP DIE VERBONDSKIND}

Kernwaardes met betrekking tot godsdienstige, maatskaplike, politieke of ekonomiese sake, vind op een of ander manier in tekste neerslag. Godsdienstige waardes word by wyse van analogiese taal soos gelykenisse, metafore en ander simbole gekommunikeer. Ontwikkelinge op die gebied van die sosiologie, en in besonder die kennissosiologie, het ons geleer dat waardes wat so in tekste uitgedruk word, as legitimering dien van teoretiese oortuigings met betrekking tot die transendente werklikheid, dit wil sê met betrekking tot die eerste beginsels van die werklikheid die essensie van bestaan. 'n Teks is, só gesien, die produk van die sosiale wêreld wat bestaan uit sosiale strukture (instellings) wat gebou word op of voortspruit uit wat transendent van aard is (vgl ook Van Staden 1988:342-345; Kee 1989:11-12).

Sonder om skuldig te wees aan anakronisme, kan die begrip 'verbond' waarmee die gemeenskap ten tyde van die Hervorming beskryf is, ook konsepsueel gebruik word om die geloofsgemeenskap in Bybelse tye te beskryf. Die Ou Testament doen dit dikwels self, hoewel die woord 'verbond' self nie baie op die oppervlak van die Nuwe Testament aangetref word nie. Die saak waarop die begrip in die Ou Testament betrekking het, was egter geensins in die tyd van Jesus onbelangrik nie. Daar is vandag selfs Nuwe-Testamentici (bv Van Tilborg 1986:31-43; Kee 1989:70-102) wat die institusionele orde waarvan die Nuwe Testament getuig, en die teologiese kernwaardes wat ten grondslag van hierdie sosiale orde lê, as essensieel verbonds- 
matig' van aard wil beskryf. Van Tilborg toon ook oortuigend aan dat die begrip 'barmhartigheid' (in Grieks uitgedruk deur o a ě $\lambda \epsilon \sigma_{\zeta}$ ) die sentrale motief van die Bybelse verbondsgedagte is: 'It is unthinkable to have a Jewish covenant without love, mercy, compassion, pity, fidelity, etc...' (Van Tilborg 1986:31-32).

Met die uitdrukking 'institusionele orde' word bedoel dat 'n ewewigtige samelewing uit bepaalde sosiale instellings bestaan waarvan een die oorkoepelende is en die ander op 'n ondergeskikte wyse daarby ineengeskakel is. Vier basiese sosiale instellings of strukture kan na bewering in enige samelewing onderskei word: ekonomie, politiek, gesinslewe en godsdiens. In sekere samelewings vandag is ekonomie die krag onderliggend aan sosiale relasies. Dit kan ook wees dat politici die kontrole uitoefen oor ekonomiese en godsdienstige instellings. Daar is egter ook samelewings waar families en die hoofde van families die kontrole uitoefen. Die eersteeeuse Mediterreense wêreld is hiervan 'n voorbeeld (kyk Malina 1986). In sulke samelewings is die ekonomie, politiek en godsdiens ingebed in 'n institusionele orde wat primêr deur geboorte en nasionaliteit bepaal word. Waar die begrip verbond' in die reformatoriese teologie sterk politieke konnotasies gehad het, hou dit, wat die Bybelse tyd betref, veral met familiale ordeninge verband. Ten opsigte van so 'n institusionele orde is die onderskeid tussen entiteite soos die burgerlike gemeenskap teenoor die kerklike gemeenskap wat in die reformatoriese tyd relevant was (kyk Pont 1986:29-32), 'n anakronistiese aangeleentheid. Die huishouding as familiale groepering, en nie die magistraat en wat hy alles verteenwoordig het nie, was die mees fundamentele sosiale entiteit in die Israelitiese en latere Joodse en Hellenistiese samelewing (vgl ook o a Neusner 1987:331-361).

So 'n huishouding was 'n selfversorgende ekonomiese eenheid soos byvoorbeeld dié van 'n ambagsman. Die pater familias was die hoof van 'n 'uitgebreide familie', wat sy vrou, die oudste seun en sy familie, sy jonger broers, hulle vrouens en familie, die ongetroude sussies, die slawe en afhanklike ambagslui in diens van die huishouding ingesluit het. Die een huishouding het na die ander uitgereik sodat 'n mens van uitgebreide families kan praat wat in 'n dorpie saamgewoon het. Hoewel die elite huishoudings (wat 'n politieke rol vervul en die tempel beheer het) in die tyd van Jesus, in 'n sekere sin geen wesenlike kontak met die nie-elites (waaronder ook Jesus, sy dissipels en ander wat die 'volk van die land' genoem is) gehad het nie, kan 'Israel' in 'n omvattende nasionale en religieuse sin van die woord beskou word as 'n versameling huisgesinne. Naas die Romeinse amptenare was die politieke regeerders hoofsaaklik gevind onder die Judese Sadduseërs en Galilese Herodiane.

Sedert Ou-Testamentiese tye was die orde in die Israelitiese geloofsgemeenskap as verbond onlosmaaklik gekoppel aan die wyse waarop die Shema-gebed konstitutief gefunksioneer het. Hierdie gebed kan waarskynlik beskou word as 'n uiting van 
klaarblyklik die mees primère godsdienstige kernwaarde wat in die Ou en Nuwe Testament terug te vind is. Dit kom veral duidelik na vore in die Markaanse gebruik van die Shema-gebed deur Jesus (Mark 12:29) en die skrifgeleerde (Mark 12:32) as inleiding tot die 'grootste gebod', die eis om liefde vir God en vir die naaste: 'Luister Israel, die Here ons God is die enigste Here.'

Hierdie gebed is uitdrukking van die oortuiging dat die skepping van God orde is; so bestempel die Nuwe-Testamentikus, Neyrey (1988:79), dit as 'God's creationas-ordering'. Dit bevat die belydenis dat die God van Israel die enigste God is met die implikasie dat God sy verbondsvolk, Israel, ook onderskei van alle ander nasies. Die implikasie daarvan is dat God se 'heiligheid' gerepliseer word in die wèreld van die mense. Alle dinge in die skepping behoort dus hiervolgens uitdrukking te wees van die Goddelike orde met betrekking tot sowel klassifikasie as diskriminasie (Neyrey 1988:68). Hierdie 'Goddelike orde' word besonderlik uitgedruk met die woord heiligheid. In hierdie verband dink ons veral aan Levitikus 19:2: 'Wees heilig, omdat Ek, die Here julle God, heilig is' (vgl ook 1 Pet 1:16). Die Griekse woord äy

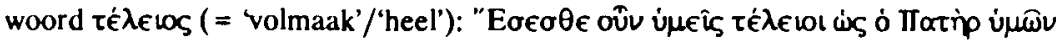

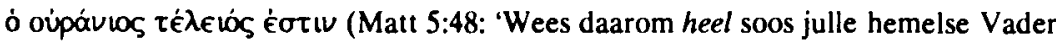
heel is'). Die antropoloog Mary Douglas (1966:54) formuleer dit soos volg: '...to be holy is to be whole, to be one; holiness is integrity, perfection of the individual and of the kind.' Hierdie 'heelheid' het dus gegeld vir byvoorbeeld die offeraar sowel as die offerdier. Om 'heilig' te wees soos God 'heilig' is, is met ander woorde om by God te pas, dit wil sê om 'heilig en onberispelik' (áyia kaì ă $\mu \omega \mu o \varsigma$ - Ef 5:27) te wees, 'sonder vlek of rimpeling of iets dergeliks' (vgl Van Aarde 1990:251-263). Verminktes ( $\theta \lambda a \delta$ ías kal árokeko $\mu \mu$ évos - Deut 23:1 LXX), gestremdes en heidene is hiervolgens nie aanvaarbaar vir God nie, en is derhalwe ook nie toegelaat om in die kultiese ruimte waar God woon, die tempel, of die vergadering van die "heili-

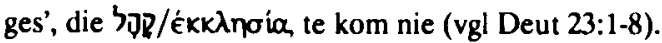

Wat verder in hierdie verband in ag geneem moet word, is dat ook vrouens en kinders van gelowige mans beperk was met betrekking tot hulle toegang tot die "heilige' van die heiligdom. In 'n sekere sin het ook die gelowige man en selfs die priester in hierdie opsig ' $n$ beperking met betrekking tot die toegang tot die 'heiligste' van die heiligdom ervaar. Dit kom daarop neer dat die Jode God se teenwoordigheid gereguleer het. Hulle Godsbegrip kom daarop neer dat God as beperk teenwoordig by die mense voorgestel is. Die regulasies waarmee God as afwesig of teenwoordig verklaar is, het uit die talle reinheidsvoorskrifte bestaan. Dit het veral vir die tempel, die tempeltoebehore, die tempelpersoneel en die aanbidders in die tempel gegeld. 
Studies in hierdie verband het breedvoerig aangetoon hoe die 'teologie' van veral die Fariseërs van die periode vóor 70 n C (dit wil sé, voordat die tempel deur die Romeine verwoes is) daarop gerig was, soos die Nuwe-Testamentikus Elliott (1991a) dit uitdruk, 'to extend into the day-to-day living of ordinary Jews the concerns of ritual purity usually associated only with the priests and Temple' (vgl veral ook Neusner 1973; Saldarini 1988). Elliott (1991b) formuleer dit op 'n ander plek soos volg: 'Particularly in Pharisaic ideology, food and meals formed a mediating link between the Temple with its altar and the private home and its table. For the Pharisees, the rigorous purity regulations pertaining to the Temple, its priesthood and sacrifices, were extended to the bed and board of every observant Jew.' Hiervoor het die Fariseërs nie net die 'Ou Testament' ingespan nie maar ook die 'tradisies van die oudstes' (vgl ook Malina 1988:30-30; Pilch 1988:31-62; Neyrey 1988: 63$91 \mathrm{to}$ v Mark 7 in hierdie verband). Hulle het 'n omvat tende klassifikasie-sisteem opgestel waarvolgens feitlik alles in die alledaagse lewe in terme van aanvaarbaarheid, dit wil sê 'heiligheid', gerangskik is. Neyrey (1988:76) verwys in aansluiting by Mary Douglas hierna as 'boundaries' en praat van 'maps of time, maps of persons, maps of things', en 'perhaps it is fair to say that their primary map was a map of meals'. Maaltye is 'n belangrike sosiologiese meganisme wat kontrole uitoefen ten opsigte van reinheid al dan nie (vgl veral Van Staden [1991]:193-232). Dit het ook direk in verband gestaan met die handhawing van 'boundaries' met betrekking tot die vermyding van 'n ondertrouery tussen Jood en nie-Jood sodat die integriteit van die familiale gemeenskap beskerm kon word. 'Accordingly, codes defining social, sexual, and food purity and pollution will form one unified complex of concerns' (Elliott 1991b).

In die tyd van Jesus was dit 'n ernstige dispuutpunt tussen die Sadduseërs en die Fariseërs of die tempelmaatreëls ook in die alledaagse lewe gerepliseer behoort te word of nie (Saldarini 1988:234; Van Aarde 1991c). Die Farisese replisering van die tempelgemeenskap na die alledaagse lewe het die religieuse implikasies gehad dat sosiale ostrasering gelegitimeer is met Godsvervreemding. Sosiaal-veragtes (soos stommes, dowes, blindes, melaatses, gestremdes, tollenaars en nie-Jode) is nie net 'sondaars' genoem nie, maar dikwels ook 'duiwelbesetenes'. Diesulkes kon in beginsel volgens die Judaïsme nie God se teenwoordigheid ervaar nie, omdat hulle nie die tempel kon betree buiten die 'voorhof van die heidene' nie. Volgens Farisese maatreëls is gevolglik geen gemeenskap met 'sondaars' in die daaglikse lewe geduld nie. En dit het veral vir die gemeenskaplike maaltyd gegeld en die hieruit voortspruitende normale sosiale versorging.

Net soos die Fariseërs, het Jesus ook gemeen dat die tempelgemeenskap gerepliseer moet word na die alledaagse lewe. Jesus het egter sosio-religieuse ostrase- 
ring teëgestaan. Anders as sy Farisese opponente het Hy in hierdie verband by 'n bepaalde tendens aangesluit wat in die Ou Testament (en tussen-testamentêre literatuur) waarneembaar is (vgl Van Aarde 1991c). Dit is naamlik die feit dat die aanvanklike eksklusivisme met betrekking tot die toegang tot die fisiese tempelgebou matiger geraak het sodat daar van 'n tendens van verruiming van die tempel gepraat $k$ an word. Die eerste aanduiding van die tendens van verruiming van die tempel word reeds in die Tweede Tempel-periode aangetref.

Rost (1938:151) is waarskynlik reg deur te sê dat Deuteronomium 23:1-8 in

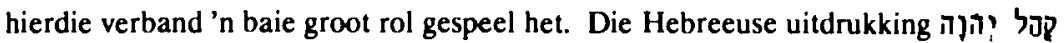
word in hierdie Ou-Testamentiese gedeelte meer as een keer gebruik. In die $\mathrm{Ou}$ Testament het 'קQ betrekking op 'n 'Aufruf zu einer Versammlung' (Rost 1938:31):

Aufgebot umfaßt mit Ausnahme von Jer. 44,15 und Esr. 10,1; Neh. 8,2-17 nur den סУ, die Gesamtheit der männlichen Volbürger. Die ausgenommen Stellen ziehen auch Frauen (und Kinder) zum Aufgebot heran...Zweck des Aufgebots ist der Zusammentritt der Mannschaft zur kultischen Feier, zur Gerichtszitzung oder zum Heerzug.

(Rost 1938:31-32)

Kritzinger (1957:11) stem met Rost saam dat daar baie tekste in die Ou Testament is wat daarop dui dat slegs volwasse mans of 'n deel van hulle as lede van die 'volksvergadering' gereken is. Maar hy meen ook dat daar ander tekste is 'waar nie met sekerheid vasgestel kan word of oy slegs manne of ook wel vrouens en kinders aandui nie' (Kritzinger 1957:11). Hoe dit ook al sy, in Deuteronomium 23:1-8 word die

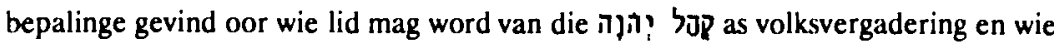
nie. Onder andere was die volgende persone vir altyd uitgesluit: iemand wie se ge-

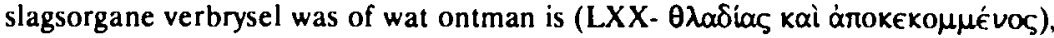
kinders uit 'gemengde huwelike', Ammoniete en Moabiete. Kinders uit die derde geslag Edomiete en Egiptenare mag egter lid geword het. Na die vernietiging van die tempel van Salomo idealiseer die profeet Esegiël (hfste 40-48) 'n nuwe tempel. Esegiël voorsien dat die Sadokiete as priesters (Eseg 44:15-16) en as regters (Eseg 44:24) van 'n nuwe kultiese gemeenskap sal funksioneer. Hulle sal die 'volk onderrig oor die onderskeid tussen wat gewyd en wat nie gewyd is nie en hulle leer om te onderskei tussen wat rein en wat onrein is' (Eseg 44:23). Die stad self sal genoem word: 'Die Here is daar' (Eseg 48:35). Maar ook Esegiël het steeds sy voorbehoud oor die reg van toegang gehad: 'So sê die Here my God: 'Geen eerlose, onbesnede uitlander mag in my heiligdom kom nie, nie een van al die uitlanders wat tussen die Israeliete woon nie' (Eseg 44:9). In Deutero-Jesaja word egter voorsien dat hierdie beperking opgehef kan word (Jes 56:3,7) en dat God se teenwoordigheid nie tot die inwoning in die tempel beperk kan word nie (Jes 66:1). 
Hieruit is dit duidelik dat daar in die Tweede Tempel-periode begin is met ' $n$ proses van geestelike bouwerk wat ons die teologiese verruiming van die tempel en die verbondsgemeenskap kan noem. Dit kan aan die begin onder andere daarin gesien word dat in Nehemia se tyd die tempelpersoneel opdrag kry om ook die herboude mure van Jerusalem te wy, so asof die heiligdom verruim geraak het. Die stad word gevolglik, na analogie van die teenwoordigheid van die Heilige God (Lev 11:44) 'heilig' genoem. Hierdie verruiming hou verband met ander gedeeltes in die boek Nehemia, maar ook in ander dele van die Kronistiese vertellinge, waar daar ten opsigte van die konstituering van die volksvergadering begin is om die eksklusiwiteit prys te gee. Vrouens en kinders word nou in die volksvergadering ingesluit. In die tussen-testamentêre literatuur is daar verder heelwat opmerkings oor hoe die mens met God versoen kan word buite die tempelkultus om (vgl Breytenbach 1989: 199-201). Veral die literatuur van die Qumram-gemeenskap is hiervan 'n sprekende voorbeeld (kyk Van Aarde 1991c). Hier word die tempel geheel en al as korrup gesien (vgl 1 Q pH 8:8-13; 12:9) en word die geloofsgemeenskap te Qumran voorgestel as 'die ware tempel van die teenswoordige tyd'. In hierdie verband is dit interessant dat die Qumran-gemeenskap ook die term 'huishouding' gebruik om na hulleself te verwys (I Q S 5:6; 8:5, 9; 9:6). Hierdie huishouding word ook 'heilig' genoem (I Q S $8: 5 ; 9: 6)$. Dit is die ruimte waar versoening geskied, maar eksklusief vir hulleself (1 Q S 5:5-7; 8:4-10; 9:3-5; 1 O Sa 1:3).

Die Jesus-beweging het volgens die berigte in die Nuwe Testament nie soos die Esseners sy rug op die tempel as woonplek van God gedraai nie. Jesus word egter wel geteken as iemand vir wie die tempel as ' $t$ ware sonder verskillende voorhowe was (kyk Conzelmann 1963:123 m b t die Jesus-beeld in die Luk-Hand korpus). Die deurbreking van die partikularisme het in die Nuwe Testament op verskillende maniere neerslag gevind. Waar die eksklusiwisme van Deuteronomium 23:1-8 op die Jerusalemse tempel toegepas is deurdat dit die uitleg van die tempel se aparte voorhowe bepaal het, is dit opvallend dat daar in die allegorese van Efesiërs 5:27 oor die

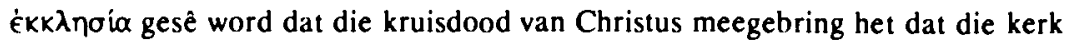

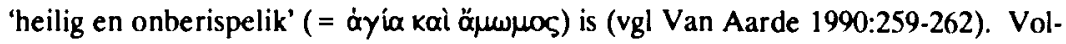
gens Origines is dit woorde wat antiteties sinspeel op die 'verminking' ( $\theta \lambda a \delta$ iac kai

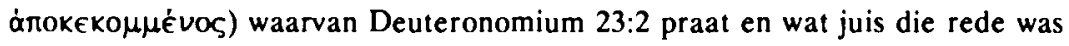
waarom s6 'n persoon geostraseer is en nie lid van die ékk $\lambda$ nớa kon wees nie. Die vertellinge in Handelinge oor die genesing van verlamdes en kreupeles in ' $n$ Samaritaanse stad (Hand 8:7) en die gelowig word en doop van manne èn vroue (Hand 8:26-39), kan ongetwyfeld ook in verband gebring word met die deurbreking van eksklusiwisme en ostrasisme. Matteus, as 'n verdere voorbeeld, vertel nie net van die skeur van die voorhangsel van die tempel (Matt 27:51) en die geloofsbelydenis 
van 'n nie-Jood (Matt 27:54) na aanleiding daarvan nie; hy vertel ook dat Jesus blindes en kreupeles, as 'onrein' sosio-religieuse randpersone, in die tempel $(=\dot{\epsilon} v \tau \hat{\varphi}$

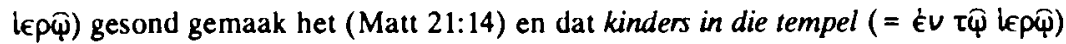
Jesus as die seun van Dawid geëer het (Matt 21:15).

In die begin van hierdie studie het ons juis daarop gewys dat die benaming 'seun van Dawid' in die Matteus-evangelie te make het met die 'aanwysing' en 'roeping' om 'n spesifieke barmhartigheidsrol te vervul en dat dit veral in verband staan met Jesus se rol as God-by-ons om die 'volk' van hulle 'sondes' te bevry. Dit is ook in hierdie verband dat Matteus in aansluiting by Psalm 107:10 (Ps 106 LXX) (kyk Gundry 1975:107) na die 'volk' verwys as diegene wat woon in die land in die skaduwee van die dood (Matt 4:16). Vir dié sosio-religieuse geostraseerdes, die volk wat in duisternis lewe', was die evangelie van Jesus, naamlik dat die koninkryk van die hemel naby gekom het, as 't ware 'n lig wat opgegaan het (Matt 4:16). Verder is dit opvallend dat hierdie 'volk' op baie plekke in die Matteus-evangelie die geringes (ol

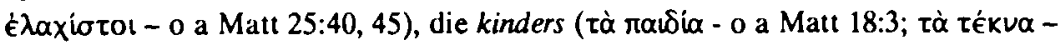

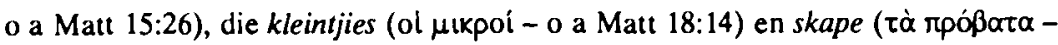
o a Matt 18:12; vgl ook Matt 10:36 en 15:26) genoem word.

Die metaforiese gebruik van 'skaap' ( = tò rpó $\beta \alpha t o v$ ) in Matteus 9:36 en 18:12 korreleer onderskeidelik met die uitdrukkinge 'die verlore skape van die huis van Is-

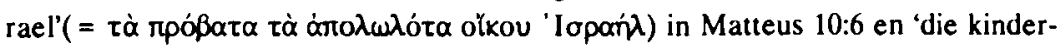

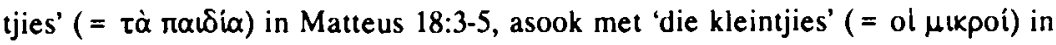
Matteus 18:6, 10, 14 (vgl ook Matt 10:42). Met behulp van hierdie benaminge word

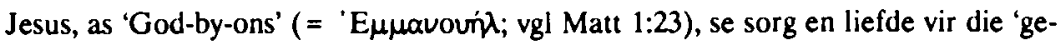
ringes' geteken (kyk verder Van Aarde [1991a]). Die Evangelis vertel dat Jesus, self 'n sosiaal-veragte vanuit die gesigshoek van die Fariseërs (vgl Matt 12:24), persoonlik nie Godsvervreemding ervaar het nie, maar wel Godsteenwoordigheid (Van Aarde 1988:829-846). Sy boodskap dat God se koninkryk in en deur sy lewe 'n werklikheid geword het, getuig hiervan. In die Markus-evangelie kan dit ook gesien word in byvoorbeeld die eksorsisme (duiweluitdrywing) van die heidense vrou se kind (Mark 7:24-30), die genesing van die doofstomme (Mark 7:31-37) en die blinde aan wie se oë Jesus 'onrein' spoeg smeer (Mark 8:22-26). Jesus vervang met ander woorde nie die tempel soos die Esseners beoog het nie; net soos die Fariseërs repliseer Hy die tempelmaatreëls, maar, anders as die Fariseërs, verruim Hy die tempel met die gevolg dat die sosio-religieuse randpersoon by maaltye by huise (Mark 12: 39) sowel as in die tempel (Mark 12:41-44) welkom is. Dit is waarop sy reiniging van die tempel neergekom het toe Hy volgens Markus 11:17 aanhaal uit Jesaja 56:17: Die tempel is ' $n$ huis van gebed vir alle mense. 
Teen hierdie agtergrond is dit soveel meer begryplik waarom die Kinderevangelium in Markus 10:13-16 geplaas is tussen die egskeidingsdebat (Mark 10:1-12) en die vraag van die ryk jonkman oor die barmhartigheidsimplikasies van om gehoorsaam te wees aan die Wet wat insluit 'eer jou vader en moeder' (Mark 10:17-31) (vgl ook o a Wenham 1982:113-118; Robbins 1983:54-55).

\section{DIE SITZ IM LEBEN VAN DIE KINDEREVANGELIUM}

Ons het gesien dat Markus 10:13-16 sedert die dae van die Reformasie met die kinderdooppraktyk in verband gebring is (kyk ook Ludolphy 1973:31-51 se oorsig van die werkgeskiedenis van Mark 10:13-16). Dit is steeds in die 'moderne tyd' so (kyk o a Cullmann 1948:65-73; Jeremias 1958:61-68; Lindemann 1983:77, 97-99). Vandag word hierdie direkte koppeling tussen die kinderdooppraktyk as sodanig en die Kinderevangelium nie sonder meer aanvaar nie (kyk o a Aland 1961:67-71; Klein 1970:68-69; Schweizer 1975:112; Gnilka 1979:81; Sauer 1981:27-29; Derrett 1983:13; Ringshausen 1986:34-42; Schmithals 1986:445-446). Wat vorm betref, vertoon Markus 10:13-16 die kenmerke van wat Dibelius 'n 'paradigma' en Bultmann 'n 'apoftegma' genoem het. Sonder om in besonderhede hierop in te gaan, kom dit daarop neer dat die Kinderevangelium ' $n$ mikrovertelling is wat formeel te onderskei is van byvoorbeeld die 'gelykenis' en die 'wondervertelling'. Bultmann het daarop gewys dat die kinders as karakters in hierdie vertelling ook as 'beeld', dit wil sê as 'simbool' van 'n 'saak' gesien moet word - so asof ons hier met 'n soort 'gelykenis' te doen het: 'das Bild wird zur Sache selbst' (Bultmann 1964:215). Sauer (1981:41-45) het egter baie oortuigend aangetoon dat Markus 10:13-16 ' $n$ 'mengvorm' is wat eerder die kenmerke van 'n 'wondervertelling' vertoon. Invloedryke studies het onafhanklik of bewustelik Sauer hierin ondersteun (kyk Crossan 1983:87; Derrett 1983: 1-2; Ringshausen 1986:41). Wat onmiddellik opvallend is, is dat die inleiding van Markus 10:13-16 sterk ooreenkoms toon met ander genesingsvertellings waar die gestremde(s) na Jesus as 'wonderdoener' gebring word met die beroep dat Hy genesing sal bewerkstellig (vgl Klein 1970:59; Pesch 1977:131; Sauer 1981:41; kyk veral Schmithals 1986:445). Vir ons doeleindes kan daar, terminologies gesien, op die volgende aspekte van hierdie ondersoek gewys word:

- 'na Jesus toe bring' (rрooфé $p \omega$ ): in die Sinoptiese Evangelies word hierdie uitdrukking uitsluitlik gebruik om te verwys na die naderbring van gestremdes en siekes sodat hulle genees kan word (Mark 2:4 par; Matt 4:24 = 14:35; Matt 8:16

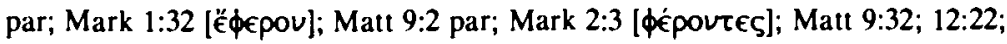

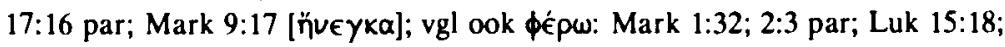
Mark 7:32; Mark 8:22; Mark 9:19-20 par; Matt 17:17; Hand 5:16; uitgesluit: Matt 18:24; Luk 23:14;); 


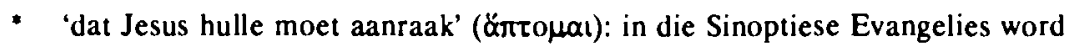
hierdie uitdrukking alleen in verband met wondergenesings en opwekkingsvertellings gebruik (Mark 1:41 par; Matt 8:3/Luk 5:13; Mark 3:10 par; Luk 6:19; Mark 6:56 par; Matt 14:36; Mark 5:27-28 par; Matt 9:20-21/Luk 8:44; Mark

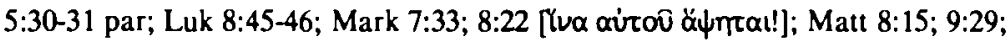
17:7 (met toespeling op 'n opwekking vanuit die dood); Matt 20:34; Luk 7:14; 8:47; 22:51; uitgesluit: Luk 7:39);

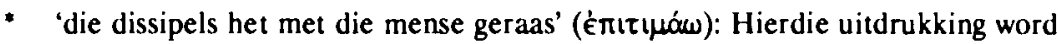
meermale in die Nuwe Testament gebruik in verband met wondervertellings (Mark 1:25 par; Luk 4:35; Mark 4:39 par; Matt 8:26/Luk 8:24; Mark 9:25 par; Matt 17:18/Luk 9:42; Mark 10:48 par; Matt 20:31/Luk 18:39; vgl ook Luk 4:39 en die sg Markaanse swyggebod in Mark 3:12 par, Matt 12:16/Luk 4:41; buite

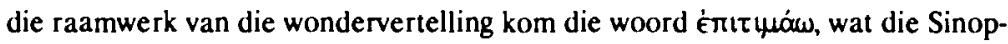
tiese Evangelies betref, slegs in die sg Petrus-belydenis in Mark 8:30, 32, 33 par en in die Lukaanse redaksie in o a Luk 17:3, maar ook in die Lukaanse eiemateriaal in Luk 19:39 en 23:40 voor);

- 'moenie die kinders verhinder nie' ( $k \omega \lambda u ́ w)$ : Hierdie woord op sigself het nie, soos onder andere Cullmann en Jeremias na aanleiding van Handelinge 8:36 gemeen het, met die dooptradisie te doen nie; 'n moontlike doopformule sal na

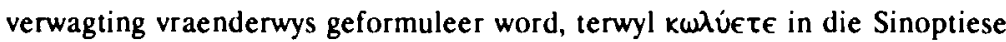
Evangelies alleen as ' $n$ imperatief of stellenderwys as 'n indikatief voorkom (Klein 1970:69; Pesch 1977:132; Sauer 1981:41); wat wel opvallend is, is dat die onderhawige werkwoord in Matteus alleen in verband met die parallelle konteks, te wete Matteus 19:14, voorkom en in Markus nog twee keer in een en dieselfde perikoop wat 'n wonderbaarlike duiweluitdrywing as tema het (Mark 9:38-41): 'Es ist ganz evident, daß im Hintergrund dieser Perikope Probleme ur-

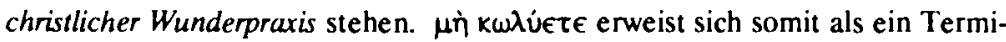
nus, der Raum dieser Praxis zumindest nicht unüblich war' (Sauer 1981:42); 1 Korintiërs 14:39 is die enigste plek in die Nuwe Testament waar die uitdrukking

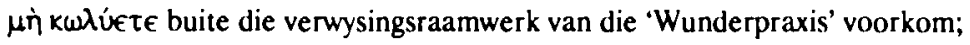

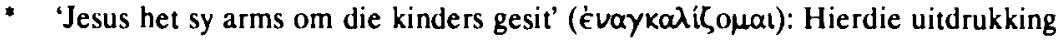
kom in die Nuwe Testament slegs in die Kinderevangelium voor en word op grond van onder andere Spreuke 6:10 en 24:33 (LXX) met 'omarm' weergegee, wat 'n affektiewe konnotasie van deernis het; by Diodorus Siculus (een jaar v C) word dit per implikasie in die konteks van die genesing van kinders gebruik:

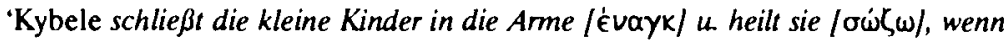
sie krank sind' (my beklemtoning - vgl ook Arndt \& Ginrich 1957:261); dit is 
daarom ook moontlik 'daß évaykalıóauevos auch in Mk 10:16 eine Heilgestus beschreibt' (Sauer 1981:42);

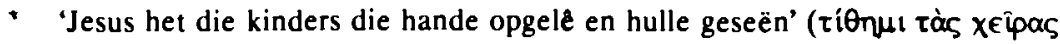

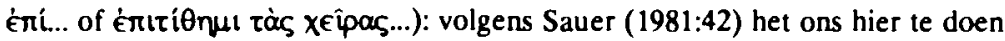
met 'ein typischer Ritus der Heilungspraxis' (vgl Mark 8:25; Mark 5:23 par [ë日nkev]; Matt 9:18; Mark 6:5; 7:32; 8:23, 25; 16:18; Luk 4:40; 13:13; Hand 28:8; vgl ook Hand 3:7); vroeër in hierdie studie het ons die saak beredeneer

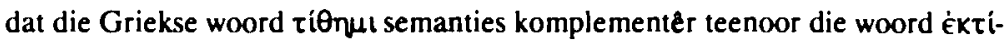
Onuı wat in die tegniese sin funksioneer, naamlik dat dit in plaas van 'om uit die huis te sit' kan beteken 'om te akkommodeer', en dat dit dikwels veral tersake was by gestremde kinders; om 'jou kind te seën', dit wil sê. in die huis te aanvaar, pas volledig in hierdie verband.

Benewens die feit dat Schmithals (1986:447-448) die Sitz im Leben van die Kinderevangelium in Markus 10:13-16 beskryf as dié wat teen die agtergrond van die genesing van geostraseerde kinders verstaan moet word, meld hy ook dat Jesus se aanvaarding van die kinders wat deur hierdie daad van Hom blyk, gesien moet word as 'n veroordeling van die praktyk van die 'uitsit van kinders uit die huis'. Dit alles pas volledig in die gegewens wat ons in veral die Matteus-evangelie gevind het. Ons het daarop gewys dat blindes en kreupeles en kinders Jesus in die tempel gevolg het nadat Hy dit gereinig het, dat Hy hulle gesond gemaak het, dat die kinders Hom as die 'seun van Dawid' geëer het en dat Jesus op die verontwaardiging van die priesterhoofde en die skrifgeleerdes reageer het met: Het julle nooit gelees nie: $U$ het daarvoor gesorg dat kinders en suigelinge u lof sing? (kyk Matt 21:12-16). Hiermee het Jesus getoon dat die verruiming in die huishouding' in die 'verruiming van die tempel as huis van God' en omgekeerd gerepliseer word. Dit kom ooreen met wat Markus na aanleiding van Jesus se reiniging van die tempel gestel het: Staan daar nie ge-

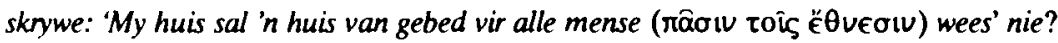
(Mark 11:17). Met betrekking tot die Kinderevangelium in Markus 10:13-16 maak Schmithals die volgende opmerking:

Die Kinder haben vollen Anteil am Heil der Gottesherrschaft, das nicht von den der menschlichen Leistung abhängt. Nimmt aber Gott sie vorbehaltlos an, dann folgt daraus mit aller Selbstverständlichkeit ihre Annahme durch die von Gott gleichfalls angenommenen Menschen. Wer gleichwertiges Glied der Gemeinde ist, muß auch im Haus voll anerkannt werden, ein SchluB, der um so selbstverständlicher ist, als 'Haus' und 'Gemeinde' in der Zeit der Hausgemeinden 
ohne-dies eine Einheit bildeten. Als Teil der Haustafel sagt unser Text also: Was Gott angenommen hat, darf der Mensch nicht verstoßen oder verachten. Die Kinder sind vollwertige Glieder der 'christliche Gesellschaft'.

(Schmithals 1986:448; my beklemtoning)

\section{GEVOLGTREKKING}

Ten spyte van die probleme wat iemand soos Karl Barth juis op grond van 'n verbondsteologie gehad het om die doop van kinders as die kontinuïteit met die OuTestamentiese besnydenispraktyk te sien, meen ek dat die doop ook as inlywing van die kinders in die kerk as verbondsgemeenskap gesien moet word (kyk Van Aarde 1984). Hierdie oortuiging word egter nie op bepaalde 'Bybeltekste' gegrond nie. Schmithals $(1977: 26-30 ; 1986: 445-446)$ is reg as hy sê dat die kinderdoop 'teologies' regverdig word, dat kinders in die Hausgemeinde hineingeboren word en dat kinders die volle Heil deelagtig is.

Die besnydenis het as 'n teken die reinheid van die kinders (meisies ingesluit) gesimboliseer wat dié besnedene later as volwasse familiehoof verwek het. Die kind in die Israelitiese verbondsgemeenskap moet in sy verhouding voor God sowel as voor die mense sodoende altyd gesien word as onregstreeks van aard. Die familiehoof het plaasvervangend vir die kind ingestaan. Dit lyk of die evangelie van Jesus Christus steeds die kind in relasie tot die ander in die verbondsgemeenskap, in die besonder die ouers, sien.

Net soos die aanvaarde rolle van die verskillende geslagte steeds bly geld het, is die verbondsbeginsel van barmhartigheid van ouers jeens kinders en lojaliteit van kinders teenoor ouers gehandhaaf (vgl bv Jesus se sterk afwysing van die ostrasering van 'n bejaarde ouer deur 'n kind in Mark 7:1-23). Die kind se verhouding met God het egter die karakter van persoonlike direktheid verkry. Teen hierdie agtergrond kan Jesus se seën van die kindertjies in Markus 10:13-16 ook in 'n ander lig as die tradisionele verstaan word.

As ontvanger van die verbondsteken word die dopeling steeds van die ongelowige onderskei, maar onbarmhartige kerklike en sosiale ostrasisme kan nie meer deur middel van die inlywingseremonie gelegitimeer word nie. Veel eerder wil die doop as verbondsteken die genadeboodskap beklemtoon dat die kind van die begenadigde ouer op geen wyse minder kind van God is as die ouer self nie. 
7. SUGGESTIES OOR DIE PLEK VAN DIE KIND IN DIE KERK VANDAG

- Die kind is op so 'n besondere wyse simbool van wat geloof en gebed is, dat die liturgie in die reformatoriese kerk verryk kan word as daar ruimte in die erediens kom dat ' $n$ kind self die Kinderevangelium in Markus 10:13-16 voorlees. So ' $n$ voorlesing deur ' $n$ kind kan onmiddellik volg op die voorlees van die Wet as die verbondsverpliginge en van die Christelike geloofsbelydenis deur die ouderling. 'Kind' en 'Oudste' vorm dus die span. Hiermee kan 'n ou praktyk in die Christelike kerk wat alreeds in die vierde eeu aangetref is, heringestel word, naamlik om 'n kind as lector in die erediens te laat voorlees (kyk Wiedemann 1989:186-188). Liturgies hoef dit nie vreemd te wees nie. Is die hele lewe van 'n kind nie juis 'n gebed nie?

- Gesang 203:1-3 kan as 'n beurtsang direk na die kinderlectio gesing word: Die kinders kan strofes een en drie sing, en die grootmense strofe twee.

- Die openbare belydenis van die geloof as 'konfirmasie' op die kind se doop behoort van die deelname aan die Nagmaal geskei te word. Alle gedooptes as verbondskinders moet aan die Nagmaal as verbondsmaaltyd ( = gemeenskapsmaaltyd) deelneem. Reeds in 1911 skryf Heitmüller soos volg hieroor:

Man erlebte das Abendmahl als Höhepunkt des Gemeindelebens mit den mannigfachsten Gefühlen und Empfindungen, aber man reflektierte im ganzen noch wenig darüber;...In erster Linie feierte man das Mahl als Gemeinschaft- oder Gemeindemahl, ganz entsprechend der Handlung Jesu und der paulinischen Anschauung...Ausdruck des Gemeinschaftsbewußtseins war das Mahl zugleich immer wieder neue Begründung und Stärkung desselben. Die uralte Vorstellung von der Bedeutung gemeinsamer Mahlzeit wirkte hier nach...Der Charakter des Brudermahles hatte unwillkürlich die Abschließung nach außen im Gefolge: nur Getaufte können teilnahmen. Der Charakter des von Liebe getragenen Bruder- und Gemeinschaftsmahles zeigt sich auch in dem Namen 'Agape' (Liebe)....

(Heitmüller 1911:77; my beklemtoning)

- Ondersoeke na die sogenoemde 'kinderkommunie' toon oorweldigend aan dat die uitsluiting van kinders van die Nagmaal nie geregverdig kan word nie (kyk o a Pel 1968; Eggenberger 1979; [s v F C S] 1979:86-87; Müller-Fahrenholz 1982; Holmes 1982; Senn 1983; Clasen \& Vos 1990:107-116; Suk 1990; Buschmann 1991; Davies 1991:12-20). 
* Hoewel dit myns insiens nie eens nodig is nie, behoort die Nederduitsch Hervormde Kerk ten minste sy Raad vir Jeugwerk opdrag te gee om 'n ondersoek na 'kinderkommunie' te loods. Insgelyks kan die Raad vir Belydenis en Liturgiese Geskrifte opdrag kry om ondersoek in te stel na die Nagmaal as verbondsmaaltyd ( = gemeenskapsmaaltyd).

- Dit spreek vanself dat daar tydens huisbesoek deur ampsdraers besondere aandag aan die kinders as wesenlik deel van die huishouding gegee behoort te word.

- Wat die prediking betref, hoef 'kinderdienste' as sodanig nie afgekeur te word nie, maar ook nie aangemoedig te word as bogenoemde aspekte in die liturgie verdiskonteer word nie. Dit spreek egter vanself dat waar die tema van 'n spesifieke preek of aspekte daarvan betrekking het op die le efwêreld van die kind, dit deeglik deur die predikant benut behoort te word. Die belangrikste is egter dat ouers en onderwysers op grond van die prediking in die erediens kinders tuis en by die skool sal leer en voorleef wat eerbied vir God alles inhou.

- Die Raad vir Kerkmusiek kan opdrag kry om sterk oorweging te gee aan die uitgee van 'n liederebundel vir gebruik deur ons jongmense by kerklike en kulturele byeenkomste. In hierdie bundel kan lekker en maklik singbare Psalms en Gesange opgeneem word wat ons gelowige kinders affektief raak. Miskien bestaan daar 'n mark hiervoor wat wyer strek as die Nederduitsch Hervormde Kerk alleen.

- Ten slotte, formeel behoort die Raad vir Opvoeding en Onderwys in die lig van die huidige sosio-ekonomiese, -politieke en -maatskaplike realiteite in SuidAfrika deeglik teologies na te dink en ondersoek te doen na die verhouding tussen kategese as verbondsonderrig en skoolonderrig. Die kerk moet dringend geadviseer word oor hoe die kerk met betrekking tot hierdie sake kerk kan wees. Miskien dwing die nuwe omstandighede in Suid-Afrika ons om die kind te herontdek. Jesus het dit immers reeds gedoen.

\section{Literatuurverwysings}

Aland, K 1961. Die Säuglingstaufe im Neuen Testament und in der alten Kirche: Eine Argument a Joachim Jeremias. München. (TEH NS 86.)

Arndt, W F \& Ginrich, F W 1957. A Greek-English lexicon of the New Testament and other early Christian literature. Chicago: University of Chicago Press.

Baker, J W 1980. Heinrich Bullinger and the covenant: The other reformed tradition. Chico: Ohio University Press. 
Bakon, S 1981. Jacob, man of destiny: His youth. Dor le Dor. Our Biblical Heritage $10 / 1,10-19$.

Bossman, D 1979. Ezra's marriage reform: Israel redefined. BTB 9, 32-38.

Boswell, J E 1984. Exposito and oblatio: The abandonment of children and the ancient and medieval family. The American Historical Review 89, 10-33.

Botha, S J 1985. Bullinger en die verbond na aanleiding van die Tweede Switserse Konfessie. HTS 41, 412-427.

Breytenbach C 1989. Versöhnung: Eine Studie zur paulinische Soteriologie. Neukirchen-Vluyn: Neukirchener Verlag. (WMANT 60.)

Bultmann, R 1964. Die Geschichte der synoptischen Tradition. 6. Aufl. Göttingen: Vandenhoeck.

Buschmann, U 1991. Plädoyer für das Abendmahl mit Kindern: Als Taufansprache oder Kurzkatechese. Homiletische Monatshefte 4, 187-188.

Clasen, F J \& Vos, C J A 1990. Kinders aan die nagmaalstafel? Praktiese Teologie in Suid-Afrika 5, 107-116.

Conzelmann, H 1963. Die Apostelgeschichte. Tübingen: Mohr. (HNT.)

Crossan, J D 1983. Kingdom and children: A study in the aphoristic tradition. Semeia 29, 75-95.

Cullmann, O 1948. Spuren einer alten Taufformel im Neuen Testament, in Die Tauflehre des Neuen Testament, 65-73. Zürich: Theologischer Verlag. (AThANT 12.)

Davies, G N 1991. The Lord's supper for Lord's children. Reformed Theological Review 50, 12-20.

Derrett, J D M 1983. Why Jesus blessed the children (Mk 10:13-16 par). NT 25, 118.

Deroux, M P 1927. Les origines de l'oblature bénédictine. Revue Mabillion 17, 1-16, 81-113, 193-216.

Dibelius, M 1961. s v 'Seneca, Lucius Annaeus'. RGG, V. Tübingen: Mohr.

Die Heidelbergse Kategismus [van 1563], 1983. Diensboek van die Nederduitsch Hervormde Kerk van Afrika, 163-203. Pretoria: KITAL.

Douglas, M T 1966. Purity and danger. London: Routledge \& Kegan Paul.

Eggenberger, H (Hrsg) 1979. Abendmahl - auch für Kinder? Grundsätzliche Überlegungen, Praxisberichte und Materialien. Zürich: Theologischer Verlag.

Elliott, J H 1991a. Temple versus Household in Luke-Acts: A contrast in social institutions. HTS 47, 88-120.

-. 1991b. Household and meals versus the Temple purity system: Patterns of replication in Luke-Acts. HTS 47, 386-399. 
Epstein, L M 1942. Marriage laws in the Bible and Talmud. Cambridge: Harvard University Press.

[s v F C S] 1979. Infant communion and church statements. Dialog 18, 86-87.

Fugel, A 1989. Tauflehre und Taufliturgie bei Huldrich Zwingli. Bern: Peter Lang. (Europäische Hochschulschriften Reihe XXIII, Band 380.)

Goodnick, B 1988. The saga of the first born. Dor le Dor. Our Biblical Heritage $16 / 3,170-178$.

Gnilka, J 1979. Das Evangelium nach Markus, 2.Teilband: Mk 8,27-16,20. Zürich: Theologischer Verlag. (EKK II/2.)

Gundry, R H 1975. The use of the Old Testament in St Matthew's gospel with special reference to the messianic hope. Leiden: Brill. (NT.S.)

Haas, M 1969. Huldrych Zwingli und seine Zeit. Zürich: Zwingli Verlag.

Horseley, R A 1979. Josephus and the bandits. Journal of Jewish Studies 10, 37-63.

Heitmüller, W 1911. Taufe und Abendmahl in Urchristentum. Tübingen: Mohr. (Religionsgeschichtliche Volksbücher für die deutsche christliche Gegenwart, LReihe, Heft 22/23.)

Holmes, U T 1982. Young children and the eucharist. New edition. New York: Seabury.

Horseley, R A \& Hanson, J S 1985. Bandits, prophets, and messiahs: Popular movements in the time of Jesus. Minneapolis: Winston.

Horst, F 1961. s v 'Segen und Fluch'. $R G G$, V. Tübingen: Mohr.

Jeremias, J 1958. Die Kindertaufe in den ersten vier Jahrhunderten. Göttingen: Vandenhoeck.

Kantenbach, F W 1961. s v 'Bodin'. $R G G$, II, 6. Tübingen: Mohr.

Kee, H C 1989. Knowing the truth: A sociological approach to New Testament inter. pretation. Minneapolis: Fortress.

Klein, G 1970. Jesus und die Kinder: Bibelarbeit über Markus 10, 13-16, in Ärgernisse: Konfrontationen mit dem Neuen Testament, 58-81. München: Kaiser.

Koch, E 1968. Die Theologie der Confessio Helvetica Posterior: Beiträge zur Geschichte und Lehre der reformierten Kirche, Band XXVII. Neukirchen-Vluyn: Neukirchener Verlag.

Kritzinger, J D 1957. Qchal Jahwe: Wat dit is en wie daaraan mag behoort. Kampen: Kok.

Liddel, H G \& Scott, R 1961. A Greek-English Lexicon. A new edition revised and augmented by $\mathrm{H}$ S Jones. New ninth edition. Oxford: Clarendon.

Lindemann, A 1983. Die Kinder und die Gottesherrschafl. (WuD NF 17.)

Loeb Classical Library 1965. s v 'The Epistle to Diognetus'. The Apostolic Fathers, II, 348-379. Transl by K Lake. London: William Heinemann. 
Louw, J P \& Nida, E A (eds) 1988. Greek-English Lexicon of the New Testament based on semantic domains. New York: UBS.

Ludolphy, I 1973. Zur Geschichte der Auslegung des Evangelium infantium, in Krause, G (Hrsg), Die Kinder im Evangelium, 31-51. Göttingen: Vandenhoeck. (PSA 10.)

Malina, B J 1986. Christian origins and cultural anthropology: Practical models for biblical interpretation. Atlanta: John Knox.

-.- 1988. A conflict approach to Mark 7. Foundations and Facets Forum 4, 3-30.

Meijer, A \& Meijer, A 1984. Matriarchal influence in the Bible: A medical-psychological study. Dor le Dor. Our Biblical Heritage 13/1, 81-87.

Müller-Fahrenholz, G (ed) 1982. '... and do not hinder them': An ecumenical plea for the admission of children to the eucharist. Geneve: WCC. (Faith and Order Paper 109.)

Neusner, J 1973. From politics to piety. Englewood Cliffs: Prentice-Hall.

-- 1975. The idea of purity in Ancient Judaism. JAAR 43, 15-26.

--- 1987. 'Israel': Judaism and its social metaphors. JAAR 55, 331-361.

Neyrey, J H 1988. A symbolic approach to Mark 7. Foundations \& Facets Fonum 4, 63-91.

-.- [1991]. s v 'Father', 'Ancestors', 'Community', 'Family'. The Collegeville Patoral Dictionary of Biblical Theology, edited by C Stuhlmuller \& D Senior. s I.

Patte, D 1987. The Gospel according to Matthew: A structural commentary on Matthew's faith. Philadelphia: Fortress.

Pel, C 1968. Avondmaalgast en kerklid: Over kindercommunie en confirmatie. Uitgegeven door de Synodale Commissie van de Evangelisch-Lutherse Kerk in het Koninkrijk der Nederlande. s I.

Pesch, R 1977. Das Markusevangelium, II. Teil: Kommentar zu Kap. 8,27-16:20. Freiburg: Herder. (HThK II, 2.)

Pilch, J J 1988. A structural functional analysis of Mark 7. Foundations and Facets Forum 4, 31-62.

Pont, A D 1985. Thomas Erastus oor die struktuur van die gemeenskap. HTS 41, 428-440.

-- 1986. Verbond en volkskerk. HTS 42, 28-76.

--- 1987. Die vrye kerk: Enkele opmerkings oor die herkoms en inhoud van die opvatting. $H T S 43,25-46$.

--- 1991. Kategese, kategismusse en die belydenis van geloof in Genève in die dae van Calvyn. HTS $47,431-441$.

Rawson, B 1986. Children in the Roman familia, in Rawson, B (ed), The family in ancient Rome: New perspectives, 170-200. London: Croom Helm. 
Ringshausen, G 1986. Die Kinder der Weisheit: Zur Auslegung von Mk 10 13-16 par. $Z N W 77,43-63$.

Robbins, V K 1983. Pronouncement stories and Jesus' blessing of the children: A rhetorical approach. Semeia 26-29, 43-74.

Rost, L 1938. Die Vorstufen von Kirchen und Synagoge im Alten Testament: Eine wortgeschichtliche Untersuchung. Stuttgart: Kohlhammer. (BWANT 76.)

Sauer, J 1981. Der ursprüngliche 'Sitz im Leben' von Mk 10 13-16. ZNW 72, 27-50.

Saldarini, A J 1988. Pharisees, Scribes and Sadducees in Palestinian society: A sociological approach. Wilmington: Michael Glazier.

Schmithals, W 1977. Noch einmal: Christsein ohne Taufe? RKZ 118, 26-30.

--- 1986. Das Evangelium nach Markus, Kapitel 9,2-16, 78. 2. Aufl. Gütersloh: Gütersloher Verlagshaus. (Ökumenischer Taschenbuchkommentar zum Neuen Testament, Band 2/2.)

Schweizer, E 1975. Das Evangelium nach Markus. 14. Aufl. Göttingen: Vandenhoeck. (NTD 1.)

Senn, F C 1983. Issues in 'infant communion'. Dialog 22, 221-227.

Smith, D J 1985. Huldrich Zwingli se 'Von dem Touff,, vom Widertouff und vom Kindertouff: Enkele aspekte van Zwingli se teologiese denke. HTS 41, 387 . 401.

Stager, L E \& Wolff, S R 1984. Child sacrifice at Carthage - religious rite or population control? Archaeological evidence provides basis for a new analysis. Biblical Archaeological Review 10/1, 31-51.

Stockton, I 1983. Children, church and kingdom. Scottish Journal of Theology 36, 87-97.

Storm , J M G 1985. Zwingli en Leo Jud se Zürichse Doopformulier. HTS 4 I, 402411.

Suk, J D [1990]. Infant communion: The historical and biblical case for its practice. Unpublished Master of Theological thesis, Calvin Theological Seminary, Grand Rapids.

Theologische Realenzyklopädie 1981. s v 'Calvin'. TRE, Band VIl: Böhmische Brüder-Chinesische Religionen, 573. Berlin: De Gruyter.

... 1989. s v 'Kind'. TRE, Band XVIII: Katechumenat/Katechumenen - Kirchenrecht, 156-176. Berlin: De Gruyter.

Thompson, Y 1986. A missing hexateuchal narrative concerning child sacrifice. Dor le Dor. Our Biblical Heritage 15, 38-42.

Transvaler, 1991. Vroue maak beswaar. 25 Junie, 7. 
Van Aarde, A G 1984. Die verbondstruktuur' in die Nuwe Testament - 'n terreinverkenning met die oog op die debat oor die verhouding kinderdoop-verbond. HTS 40/3, 28-55.

--- 1988. Jesus en die sosiaal-veragtes. HTS 44, 829-846.

--- 1990. Die 'heiligheid' van die kerk teen die agtergrond van die breuk kerk-sinagoge. In die Skriflig 24, 251-263.

--- [1991a]. 'God-with-us': The dominant 'ideological'/'theological' perspective in Mathew's story, and other Matthean essays. Forthcoming publication.

--- [1991b]. Natuurwonders, mens en omgewing: Die wonderbaarlike vind van 'n silwermuntstuk in die bek van 'n vis (Matt 17:24-27), in Vos, C J A \& Müller, J C (red), God, mens, wêreld. Pretoria: Orion Uitgewers.

--- 1991c. 'The Most High God does live in houses, but not houses built by men...': The relativity of the metaphor 'Temple' in Luke-Acts. Neotestamentica 25/1, 51-64.

Van der Walt, B J (red) 1990. Ulrich Zwingli: His message for South Africa today, in Anatomy of reformation, 115-148. Potchefstroom: PU for CHE.

Van Staden, P 1988. A sociological reading of Luke 12:35-48. Neotestamentica 22, 337-353.

--- [1991]. Compassion - the essence of life: A social-scientific study of the religious symbolic universe reflected in the ideology/theology of Luke. Pretoria: Tydskrifafdeling van die Nederduitsch Hervormde Kerk. (HTS Suppl.) (Forthcoming).

Van Tilborg, S 1986. The sermon on the mount as an ideological intervention: $A$ reconstruction of meaning. Assen: Van Gorcum.

Wenham, D 1982. A note on Mark 9:33-42/Matt.18:1-6/Luke 9:46-50. JSNT 14, 113-118.

Weaver, P R C 1986. The status of children in mixed marriages, in Rawson, B (ed), The family in ancient Rome: New perspectives, 145-169. London: Croom Helm.

Wiedemann, T 1989. Adults and children in the Roman Empire. London: Routledge. 